\title{
Deficient Nonpeptidergic Epidermis Innervation and Reduced Inflammatory Pain in Glial Cell Line-Derived Neurotrophic Factor Family Receptor $\alpha 2$ Knock-Out Mice
}

\author{
Päivi H. Lindfors, Vootele Võikar, Jari Rossi, and Matti S. Airaksinen \\ Neuroscience Center, University of Helsinki, 00014 Helsinki, Finland
}

\begin{abstract}
Most unmyelinated nociceptive neurons that mediate pain and temperature sensation from the skin bind isolectin B4 (IB4)-lectin and express Ret, the common signaling component of glial cell line-derived neurotrophic factor (GDNF) family. One of these factors, neurturin, is expressed in the epidermis, whereas its GDNF family receptor $\alpha 2$ (GFR $\alpha 2)$ is expressed in the majority of unmyelinated Ret-positive sensory neurons. However, the physiological roles of endogenous neurturin signaling in primary sensory neurons are poorly understood. Here, we show that the vast majority $(\sim 85 \%)$ of IB4 binding and $\mathrm{P} 2 \mathrm{X}_{3}$ purinoreceptor-positive neurons, but virtually none of the calcitonin gene-related peptide (CGRP) or vanilloid receptor transient receptor potential vanilloid 1-positive neurons in mouse dorsal root ganglion (DRG) express GFR $\alpha 2$. In GFR $\alpha 2$ knock-out (K0) mice, the IB4-binding and P2X $\mathrm{X}_{3}$-positive DRG neurons were present but reduced in size, consistent with normal number but reduced caliber of unmyelinated axons in a cutaneous nerve. Strikingly, nonpeptidergic (CGRP-negative) free nerve endings in footpad epidermis were $>70 \%$ fewer in GFR $\alpha 2$-KO mice than in their wild-type littermates. In contrast, the density of CGRP-positive epidermal innervation remained unaffected. In the formalin test, the KO mice showed a normal acute response but a markedly attenuated persistent phase, indicating a deficit in inflammatory pain response. Behavioral responses of GFR $\alpha 2$-KO mice to innocuous warm and noxious heat were not blunted; the mice were actually markedly hypersensitive to noxious cold in tail immersion test. Overall, our results indicate a critical role for endogenous GFR $\alpha 2$ signaling in maintaining the size and terminal innervation of the nonpeptidergic class of cutaneous nociceptors in vivo.
\end{abstract}

Key words: cold hyperalgesia; cutaneous C-fiber innervation; formalin test; IB4-lectin; neurturin; noxious heat sensation

\section{Introduction}

Cutaneous nociceptors are polymodal primary afferent neurons, the mainly unmyelinated (C-fiber) axons of which terminate as free nerve endings between the epidermal keratinocytes to mediate thermal, mechanical, and pain sensation from the skin. Most of these small sensory neurons are selectively labeled by isolectin B4 (IB4) and express the Ret receptor tyrosine kinase (Plenderleith and Snow, 1993; Molliver et al., 1997; Bennett et al., 1998b). Ret is the common signaling component of glial cell line-derived neurotrophic factor (GDNF) family ligands that bind a GDNF family $\alpha$-receptor $(\mathrm{GFR} \alpha)$ (Baloh et al., 2000; Airaksinen and Saarma, 2002). GFR $\alpha 1$, GFR $\alpha 2$, and GFR $\alpha 3$, the receptors for GDNF, neurturin (NRTN), and artemin, respectively, are expressed in partially overlapping subpopulations of Ret-positive dorsal root ganglion (DRG) neurons (Bennett et al., 1998b). Ret and GFR $\alpha$ receptor expression in DRG starts during embryonic development and continues to adulthood (Golden et al., 1999; Baudet et al., 2000). Of the GDNF family ligands, NRTN mRNA

Received Sept. 24, 2005; revised Jan. 4, 2006; accepted Jan. 5, 2006.

This work was supported by grants from the Finnish Academy and the Sigrid Jusélius Foundation (M.S.A.). We thank Kaija Berg for technical assistance and Heikki Rauvala for comments.

Correspondence should be addressed to Matti S. Airaksinen, Neuroscience Center, Viikinkaari 4, University of Helsinki, 00014 Helsinki, Finland. E-mail: mairaksi@operoni.helsinki.fi.

DOI:10.1523/JNEUROSCI.4065-05.2006

Copyright $\odot 2006$ Society for Neuroscience $\quad$ 0270-6474/06/261953-08\$15.00/0 is known to be expressed in embryonic skin epidermis as well as in adult skin (Luukko et al., 1998; Golden et al., 1999), suggesting that NRTN acts as a physiological target-derived factor for the development, maintenance, and/or function of the cutaneous Ret/GFR $\alpha 2$-positive sensory neurons.

Although exogenous NRTN promotes the survival and neurite outgrowth of DRG neurons in vitro (Kotzbauer et al., 1996; Rossi et al., 1999; Paveliev et al., 2004), GFR $\alpha 2$ knock-out (KO) mice have normal numbers of sensory axons in the saphenous nerve (Stucky et al., 2002), suggesting that the primary sensory neurons do not need GFR $\alpha 2$ signaling for survival or axon growth into the peripheral target area. Yet, whether the peripheral target innervation of the neurons (i.e., free nerve endings in the skin epidermis) is affected in these mice has not been investigated. Previous electrophysiological studies using acute DRG neuron cultures and skin-nerve preparations from adult GFR $\alpha 2-\mathrm{KO}$ mice suggest that GFR $\alpha 2$ signaling regulates noxious heat transduction but not mechanical response properties of the IB4-binding subpopulation of unmyelinated C-fiber sensory neurons (Stucky et al., 2002). However, a potential physiological role of endogenous GFR $\alpha 2$ signaling in somatosensory neuron function in vivo has not been studied. Here, we address the role of GFR $\alpha 2$ signaling in DRG neuron morphology, innervation, and function in mice. We show that GFR $\alpha 2$ is expressed predominantly by the unmyelinated IB4-binding subpopulation of mouse 
DRG neurons and that their size but not number is reduced in GFR $\alpha 2-\mathrm{KO}$ mice. We found that the $\mathrm{KO}$ mice have a profoundly reduced density of calcitonin gene-related peptide (CGRP)negative free nerve endings in footpad skin and a markedly attenuated formalin-induced inflammatory pain response. Surprisingly, temperature sensitivity of the mice in different behavioral tests was either normal or increased. Our results indicate that endogenous NRTN signaling via GFR $\alpha 2$ is needed to maintain the size, inflammatory pain responses, and terminal innervation of small nonpeptidergic cutaneous neurons. A preliminary report of this work has been published (Hiltunen et al., 2003).

\section{Materials and Methods}

Animals. The local ethics committee for animal research at the University of Helsinki approved all animal experiments. GFR $\alpha 2-\mathrm{KO}$ mice were produced and genotyped as described previously (Rossi et al., 1999). The mutation was maintained by backcrossing heterozygous animals for at least 10 generations separately for two inbred strains (129S2/SvHsd and C57BL/6JOlaHsd; Harlan, Bicester, UK), resulting in congenic B6 and 129 strains. Littermate wild-type (WT) and GFR $\alpha 2$-KO mice in $(129 \times$ B6) F1 hybrid (129B6) backgrounds were obtained by intercrossing heterozygotes from the two congenic lines (Banbury Conference on Genetic Background in Mice, 1997).

Immunohistochemistry. Littermate mice of the same gender were perfused transcardially with $4 \%$ paraformaldehyde in PBS under deep anesthesia and postfixed overnight. For $\mathrm{P}_{2} \mathrm{X}_{3}$ purinoceptor staining, some mice were perfused with calcium-free Tyrode's solution, followed by $4 \%$ paraformaldehyde and $0.2 \%$ picric acid in $0.1 \mathrm{~m}$ phosphate buffer, $\mathrm{pH}$ 6.9. Lumbar L3 and L4 ganglia, a length of lumbar spinal cord, and forepaw and hindpaw skin including the footpads were dissected, cryoprotected in sucrose, and cut into cryosections. The slides were incubated with specific polyclonal primary antibodies and biotin-labeled IB4 lectin (Sigma, St. Louis, MO) overnight at room temperature. Primary antibodies were against CGRP (rabbit; Chemicon, Hampshire, UK), GFR $\alpha 2$ (goat; R \& D Systems, Abingdon, UK), P2X 3 (guinea pig; Chemicon), protein gene product 9.5 (PGP9.5; rabbit; Chemicon), peripherin (rabbit; Chemicon), and transient receptor potential vanilloid 1 (TRPV1) (rabbit; a gift from Dr. Julius, University of California, San Francisco, $\mathrm{CA})$. Cyanine 3 (Cy3)- and Cy2-conjugated streptavidin and donkey secondary antibodies were obtained from Jackson ImmunoResearch (Cambridgeshire, UK). The embedding medium included 4',6diamidino-2-phenylindole (DAPI) to aid nuclear identification. Histological quantification was performed by an experimenter who was blind to the genotype of the samples.

Neuronal counts, colocalization, size distribution, and densitometry. To estimate the density of $\mathrm{P} 2 \mathrm{X}_{3}$-positive neurons in lumbar DRG, we used the unbiased Abercrombie Method 2 (http://www.nervenet.org/papers/ Aberfp.html\#Method2) for sections double-stained with $\mathrm{P}_{2} \mathrm{X}_{3}$ and the pan-neuronal marker PGP9.5. Briefly, immunopositive neuronal profiles (with a clear nucleus) were counted in every second pair of adjacent 10 and $20 \mu \mathrm{m}$ sections cut through the L4 ganglion. Subtraction of the sum of $10 \mu \mathrm{m}$ section counts from the sum of $20 \mu \mathrm{m}$ section counts results in an unbiased estimate of neuron number in the ganglion from which the average density of $\mathrm{P} 2 \mathrm{X}_{3}$-positive neurons (relative to total PGP9.5-positive neurons) was derived. Colocalization of GFR $\alpha 2$ with different DRG neuronal markers was estimated from four to eight sections per L4 ganglia from three to four wild-type mice using systematic random sampling. All GFR $\alpha 2$-positive profiles with a clear nucleus were analyzed from the images, and the percentage of colocalization was calculated. For soma size analysis in L4 DRG, at least 100 labeled neuronal profiles per mouse and marker were selected randomly and outlined from digital images using ImageProPlus software (Media Cybernetics, Wokingham Berkshire, UK). The intensity of IB4-binding in wild-type and GFR $\alpha 2-$ KO lumbar spinal cords (level L3-L5) was estimated from several digital images using AIDA/2D densitometry software (Raytest Isotopengeräte, Straubenhardt, Germany). The results are given as intensity per area (in arbitrary units/pixel) after subtraction of background.

Epidermis innervation. Adjacent transverse or horizontal $(15-30 \mu \mathrm{m})$ cryosections of interdigital footpads were stained for the pan-neuronal marker PGP9.5 and for CGRP. The average thickness of footpad epidermis did not differ between the genotypes (data not shown). To estimate the density of free nerve endings in the epidermis, digital images of randomly selected areas from the interdigital footpad skin were taken at $40 \times$ magnification, and the number of immunopositive nerve fibers in the epidermis within each image area was counted by carefully focusing throughout the section thickness to identify all of the fibers. The dermisepidermis borderline within the image area was traced and its length measured using the ImageProPlus software. At least 10 areas were analyzed for each footpad and marker. Similar results were obtained from the forepaws and hindpaws, so the results were pooled. The average number of PGP9.5- and CGRP-positive fibers per unit length of epidermis was then calculated for each animal. To estimate the percentage of peptidergic (CGRP-positive) and nonpeptidergic (CGRP-negative) free nerve endings in the epidermis, $20 \mu \mathrm{m}$ footpad sections from a separate set of animals were double stained for PGP9.5 (sheep polyclonal; Serotec, Oxford, UK) and CGRP. One hundred randomly selected PGP9.5positive fibers were analyzed per animal. Confocal microscopy images were taken using a $40 \times$ water immersion objective, and maximum intensity projections were generated using Zeiss (Thornwood, NY) LSM5 software.

Behavioral studies. Littermate mice (of both genders), 3-6 months of age, were used in all behavioral tests. In addition to mice in a $129 \mathrm{~B} 6$ hybrid background, congenic mice in B6 and 129 backgrounds were used as indicated. The mice were housed in groups of two to four per cage in standard specific pathogen-free conditions under a constant dark-light cycle. Food and water were provided ad libitum. Ambient room temperature was a constant $22.0 \pm 0.5^{\circ} \mathrm{C}$. The experimenter was blind to the genotype of the mice during testing.

Hot plate test. A standard hot plate (TSE, Bad Homburg, Germany), adjusted to 49.0 or $52.0^{\circ} \mathrm{C}( \pm 0.2)$, was used to assess nociceptive sensitivity. The mouse was confined on the plate by a Plexiglas cylinder (diameter, $19 \mathrm{~cm}$; height, $26 \mathrm{~cm}$ ), and the latency to the first hindpaw response (licking or shaking) was recorded.

Tail withdrawal test. The mice were gently restrained by hand, and the distal half of the tail was inserted into a water bath. The latency to withdraw the tail was recorded. The test was repeated four times with $1 \mathrm{~h}$ intertrial intervals at each temperature. The water temperature was controlled either thermostatically $\left(49\right.$ and $\left.52^{\circ} \mathrm{C}\right)$ or by a digital thermometer $\left(4^{\circ} \mathrm{C}\right.$; bath surrounded with ice).

Temperature choice test. The animals were tested in a two-temperature choice (thermotaxis) test modified from Lee et al. (2005) and Moqrich et al. (2005). The testing apparatus consists of two square aluminum plates $(20 \times 20 \times 2 \mathrm{~cm}$ thermally isolated with a 2 -mm-thick plastic spacer) enclosed within a Plexiglas chamber. The temperature of the plate was controlled with a block heater (UBD2; Grant Instruments, Cambridge, UK) and measured with a digital thermometer. One plate was kept at room temperature $\left(22^{\circ} \mathrm{C}\right)$, and the other was heated to $35^{\circ} \mathrm{C}$. Alternatively, one plate was heated to $34^{\circ} \mathrm{C}$ and the other to $36^{\circ} \mathrm{C}$. Mice were placed in the chamber and allowed to acclimate to the testing environment for $20 \mathrm{~min}$, and the total time spent on the warm surface during the following $10 \mathrm{~min}$ was recorded with a video system (EthoVision, Noldus, The Netherlands).

Mechanosensitivity. A separate set of 2- to 4-month-old mice (in B6 background) were tested for behavioral responses to mechanical stimuli using calibrated von Frey nylon filaments (tip diameter, $0.8 \mathrm{~mm}$ ). The mice were placed in an elevated plastic cage on a wire mesh floor. Von Frey hairs were applied from below to the plantar surface of both hindpaws in ascending order of stimulus force $(0.28,0.39,0.65,1.17,1.88$, and $3.29 \mathrm{~g}$ ). At threshold, the mouse withdraws its paw away from the hair. Both hindpaws were tested 10 times, and the interval between two consecutive trials on the same paw was at least $1 \mathrm{~min}$. The results are presented as the average percentage of responses against a given stimulus force.

Formalin test. Formalin-induced pain behavior was assessed as described previously (Tjolsen et al., 1992; Mogil et al., 1998) using a short anesthesia during the injection, which has been reported to reduce variability (Murray et al., 1988). Mice (4- to 6-month-old littermates in B6 
Table 1. Percentage of colocalization of GFR $\alpha 2$ with various markers in mouse lumbar (L3 and L4) DRGs

\begin{tabular}{lll}
\hline Marker & GFR $\alpha 2$-positive neurons expressing other marker & 0ther marker neurons expressing GFR $\alpha 2$ \\
\hline IB4 & $71 \%(355$ of 502$)$ & $83 \%(355$ of 426$)$ \\
Peripherin & $68 \%(278$ of 410$)$ & $64 \%(278$ of 432$)$ \\
P2X & $66 \%(412$ of 621$)$ & $85 \%(412 \text { of } 485)^{a}$ \\
CGRP & $1.5 \%(6$ of 408$)$ & $2.9 \%(10$ of 339$)$ \\
TRPV1 & $0.4 \%(1$ of 285$)$ & $0.6 \%(1$ of 167$)$ \\
\hline
\end{tabular}

The number of labeled neuronal profiles analyzed is shown in the parentheses. ${ }^{a}$ Because $47 \%$ of the mouse DRG neurons were P2X $X_{3}$ positive, it can be estimated that $\sim 40 \%$ express GFR $\alpha 2$. For comparison, GFR $\alpha 2$ mRNA is expressed by more than half of all neurons in human DRG (Josephson et al., 2001) and by $\sim 30 \%$ of all neurons in rat DRG (Bennett et al., 1998b).
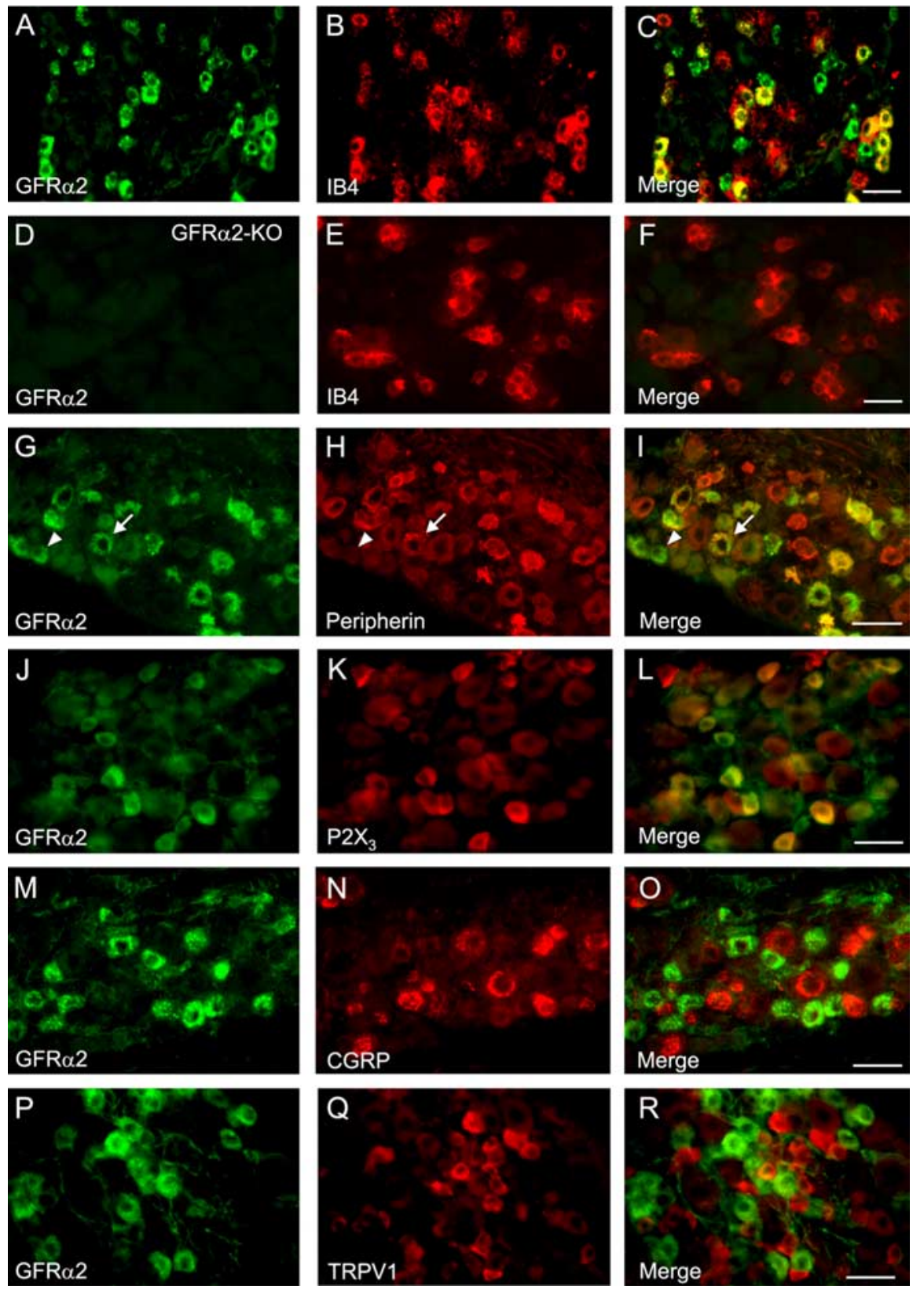

Figure 1. Colocalization of GFR $\alpha 2$ protein with markers of unmyelinated neurons in mouse DRG. Sections of wild-type ( $\boldsymbol{A}-\boldsymbol{C}$, $\boldsymbol{G}-\boldsymbol{R})$ and GFR $\alpha 2-K 0(\boldsymbol{D}-\boldsymbol{F})$ mouse lumbar L4 DRG are stained for IB4-binding $(\boldsymbol{B}, \boldsymbol{E})$, peripherin $(\boldsymbol{H}), \mathrm{P}_{2} \mathrm{X}_{3}(\boldsymbol{K}), \mathrm{CGRP}(\boldsymbol{N})$, and TRPV1 $(\mathbf{Q})$ to estimate colocalization with GFR $\alpha 2$ protein (left; green). The yellow color in the merged images (right) indicates colocalization. No specific GFR $\alpha 2$ staining is seen in the DRG section from the GFR $\alpha 2$-K0 mouse (D). Note that GFR $\alpha 2$-expressing neurons that are peripherin negative (arrowheads) appear to be similarly sized to neurons that are peripherin positive (arrows). Scale bars, $50 \mu \mathrm{m}$. background) were allowed to acclimate for 15 min in a plastic box, anesthetized briefly with isoflurane vapor (in a glass container), and injected subcutaneously with $20 \mu \mathrm{l}$ of $1.85 \%$ formaldehyde in $0.9 \%$ saline (corresponds to $5 \%$ formalin) into the plantar right hindpaw. The animals woke up within 1 min (average, 15-30 s) after the injection. The mice were observed for $60 \mathrm{~min}$ after the formalin injection, and the time spent licking or shaking the injected paw was measured (with a stop watch) in 5 min intervals. The acute phase (phase 1) was defined as $0-10 \mathrm{~min}$ after injection, and the persistent (tonic) phase (phase 2) was defined as 10-60 $\mathrm{min}$ after injection. Formalininduced footpad edema was estimated by comparing injected and noninjected (contralateral) paw thickness and weight as described by Mogil et al. (1998). Briefly, $60 \mathrm{~min}$ after the formalin injection, animals were given a lethal dose of anesthetic, and the dorsoventral thickness of both hindpaws was measured with a micrometer caliper from the middle of the hindpaw. After the animals were killed, the hindpaws were cut at the ankle joint and weighed on a microbalance.

Data are expressed as mean \pm SEM. Statistical analysis between genotypes was done either using unpaired Student's $t$ test assuming unequal variances or with one-way ANOVA with genotype as a grouping variable, as appropriate. The size distribution data were analyzed using Kolmogorov-Smirnov test.

\section{Results}

Most IB4-lectin binding and $\mathrm{P} 2 \mathrm{X}_{3}$ receptor-positive neurons express GFR $\alpha 2$ To estimate the degree of GFR $\alpha 2$ colocalization with various markers of DRG subpopulations in mice, we performed quantitative immunohistochemical analysis of DRG sections (Table 1). In mouse lumbar DRGs, $83 \%$ of the IB4-binding neurons expressed GFR $\alpha 2$, whereas of the GFR $\alpha 2$ positive neurons, 71\% bound IB4 (Fig. $1 A-C$ ). Of GFR $\alpha 2$-positive neurons, $68 \%$ colocalized with peripherin, a marker for unmyelinated neurons, and $64 \%$ of the unmyelinated, peripherin-positive neurons expressed GFR $\alpha 2$ (Fig. 1G-I). For comparison, $\sim 15 \%$ of the GFR $\alpha 2$ positive neurons in the rat express a marker for myelinated neurons (Bennett et al., 1998b). The average size of GFR $\alpha 2-$ expressing neuronal profiles that were peripherin-positive $\left(380 \pm 9 \mu \mathrm{m}^{2}\right)$ was not significantly different from those that were peripherin-negative $(344 \pm 11$ $\mu \mathrm{m}^{2}$ ), suggesting that the peripherinnegative GFR $\alpha 2$-neurons represent thinly myelinated nociceptors. Most (85\%) of the $\mathrm{P}_{2} \mathrm{X}_{3}$-expressing neurons were GFR $\alpha 2$-positive, and vice versa, $66 \%$ of GFR $\alpha 2$-positive neurons expressed $\mathrm{P} 2 \mathrm{X}_{3}$ (Fig. $1 J-L)$. In contrast, few $(1.5 \%)$ of the GFR $\alpha 2$-positive neurons coexpressed 
CGRP (Fig. 1M-O). Moreover, GFR $\alpha 2$ was not colocalized with the vanilloid receptor TRPV1 in mouse DRG neurons (Fig. 1M-O). In summary, a large majority of the small nonpeptidergic neurons in mouse DRG express GFR $\alpha 2$.

IB4-binding and $\mathrm{P} 2 \mathrm{X}_{3}$-positive neurons are smaller in GFR $\alpha 2-K O$ mice

The density of $\mathrm{P}_{2} \mathrm{X}_{3}$-positive neurons in lumbar DRGs was similar in wild-type and GFR $\alpha 2-\mathrm{KO}$ mice (WT, $47 \pm 7 \%$; KO, $45 \pm 4 \%$ of PGP9.5-positive neurons in L4 DRG; $n=4$ mice for both genotypes) consistent with identical numbers of unmyelinated axons in cutaneous nerves and IB4binding neurons in acute DRG cultures isolated from wild-type and GFR $\alpha 2-\mathrm{KO}$ mice (Stucky et al., 2002). However, the IB4-binding (WT, $463 \pm 10 \mu \mathrm{m}^{2}$; KO, $316 \pm 7 \mu \mathrm{m}^{2} ; p<0.0001$ ) (Fig. 2A-C) and $\mathrm{P}_{2} \mathrm{X}_{3}$-positive (WT, $407 \pm 6 \mu \mathrm{m}^{2}$; $\mathrm{KO}, 309 \pm 4 \mu \mathrm{m}^{2} ; p<0.0001$ ) (Fig. $2 D-F)$ DRG neuronal profiles were markedly smaller in GFR $\alpha 2-\mathrm{KO}$ mice than in their wild-type littermates, compatible with the smaller caliber of unmyelinated nerve fibers in the KO mice (Stucky et al., 2002). These results agree with the reduced size of sensory neurons expressing GFR $\alpha 2$ mRNA in NRTN-deficient mice (Heuckeroth et al., 1999). In apparent contrast to our data, the number of GFR $\alpha 2$-expressing DRG neurons is also reduced in the NRTN-deficient mice, but whether this is attributable to cell death or downregulation of GFR $\alpha 2$ expression remains unclear. As expected from the lack of GFR $\alpha 2$ expression in CGRP-positive DRG neurons in wild-type mice, the CGRP-positive neuronal profiles in GFR $\alpha 2-\mathrm{KO}$ mice were of normal size (WT, $411 \pm 13 \mu \mathrm{m}^{2}$; KO, $390 \pm 9 \mu \mathrm{m}^{2} ; p=$ 0.12) (Fig. 2G-I).

Many CGRP-negative free nerve endings are missing in GFR $\alpha 2-K O$ mouse footpad epidermis

Free nerve endings in the glabrous footpad skin were visualized using antibodies against CGRP and pan-neuronal marker PGP9.5. Almost all nerve fibers in the epidermis are unmyelinated (either CGRPpositive or nonpeptidergic) free nerve endings (Zylka et al., 2005). Fiber density and labeling intensity of the subepidermal nerve plexus in the footpad dermis appeared similar between the genotypes (Fig. $3 A-E)$. In contrast, the density of PGP9.5-positive nerve fibers in the epidermis appeared clearly reduced in GFR $\alpha 2-\mathrm{KO}$ mice compared with wild-type mice (Fig. $3 A, B$ ), whereas the density of CGRPpositive nerve fibers appeared similar between the genotypes (Fig. $3 D, E)$ (data not shown). Quantification of the fiber density per unit length indicated that the epidermal density of CGRP-positive nerve fibers was unchanged in GFR $\alpha 2-\mathrm{KO}$ mice (Fig. $3 C)(p=0.2 ; n=4$ for both genotypes). In contrast, there was $\sim 70 \%$ less PGP9.5positive fibers in epidermis per unit length in $\mathrm{KO}$ mice than in wildtype mice (Fig. $3 C$ ) ( $p<0.001$ between genotypes; $n=8$ for both).

Because direct identification of the nonpeptidergic fibers in skin is difficult (Zylka et al., 2005), we quantified the extent of colocalization of CGRP within the PGP9.5-positive fibers in the footpad epidermis from additional wild-type and $\mathrm{KO}$ mice $(n=$
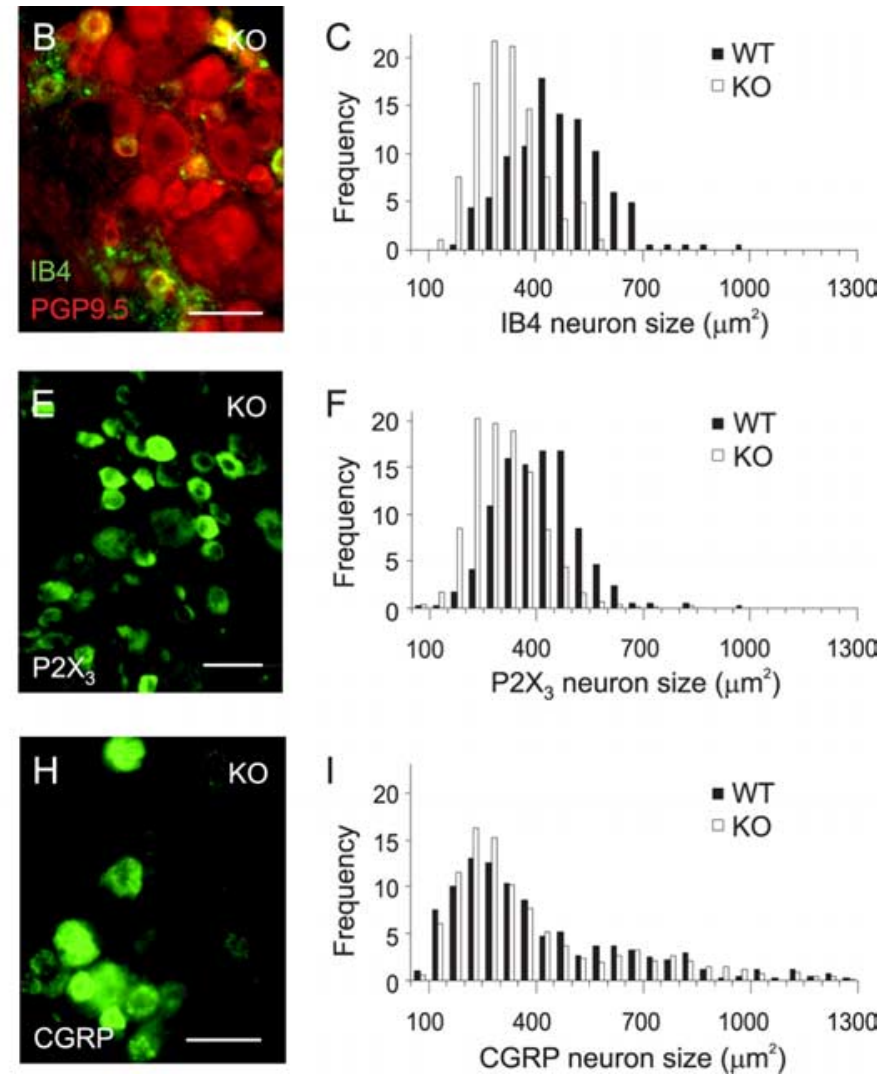

Figure 2. IB4-lectin binding and $\mathrm{P} 2 \mathrm{X}_{3}$-positive neurons are smaller in $\mathrm{GFR} \alpha 2-\mathrm{K} 0$ mice. Representative images of IB4-binding $(\boldsymbol{A}, \boldsymbol{B}), \mathrm{P} 2 \mathrm{X}_{3}$-positive $(\boldsymbol{D}, \boldsymbol{E})$, and CGRP-positive $(\boldsymbol{G}, \boldsymbol{H})$ neurons in adult lumbar DRG from wild-type $(\boldsymbol{A}, \boldsymbol{D}, \boldsymbol{G})$ and $G F R \alpha 2-K 0(\boldsymbol{B}, \boldsymbol{E}$, $\boldsymbol{H})$ mice, which were used to count the neurons and to generate the size distribution histograms $(\boldsymbol{C}, \boldsymbol{F}, \boldsymbol{I})$, are shown. Note the atrophy of IB4-binding and P2X $X_{3}$-positive but not CGRP-positive neurons in GFR $\alpha 2-K 0$ mice. Scale bars, $50 \mu \mathrm{m}$.

3 for both genotypes) as an independent estimate of the fiber loss. As expected, all CGRP fibers were PGP9.5 positive (Fig. $3 D, E$ ). In the wild-type mouse epidermis, CGRP was expressed by $27 \%$ of PGP9.5-positive nerve endings, whereas in the KO mouse epidermis, 56\% of the remaining PGP9.5-positive nerve fibers expressed CGRP. From this, assuming that the CGRP-positive fibers are unaffected, it can be estimated that 52\% of all PGP9. 5 -positive nerve fibers were missing in the $\mathrm{KO}$ epidermis. [For 27 CGRP-positive fibers in $\mathrm{KO}$ mice, 21 (44\% of $27+21)$ fibers are CGRP negative, and thus $52(=100-27-21)$ fibers are lost.] This corresponds to a loss of $71 \%(=21 / 73-1)$ of the CGRPnegative nerve fibers. Together, the results show that the vast majority of nonpeptidergic (and $50-70 \%$ of all) free nerve endings are missing in the GFR $\alpha 2-\mathrm{KO}$ mouse footpad epidermis.

To study whether GFR $\alpha 2$ signaling is critical for the spinal projections of nonpeptidergic neurons (Snider and McMahon, 1998; Hunt and Mantyh, 2001), we analyzed lumbar spinal cord sections for IB4 binding. The density of IB4 binding in inner lamina II of dorsal horn was comparable between the genotypes (WT, $2.8 \pm 0.1 ; \mathrm{KO}, 3.0 \pm 0.5$ arbitrary units; $p=0.6$ ) indicating that central target innervation of the nonpeptidergic neurons is not affected in GFR $\alpha 2-\mathrm{KO}$ mice (Fig. 4).

GFR $\alpha 2-K O$ mice show normal behavioral responses to innocuous warm in the temperature choice test and to noxious heat in the hot plate test but are hypersensitive to hot and cold in the tail

immersion test

Neurons from GFR $\alpha 2-\mathrm{KO}$ mice have a defect in heat transduction in vitro (Stucky et al., 2002). To assess noxious temperature sensitivity in vivo, we first used the standard hot plate and tail 


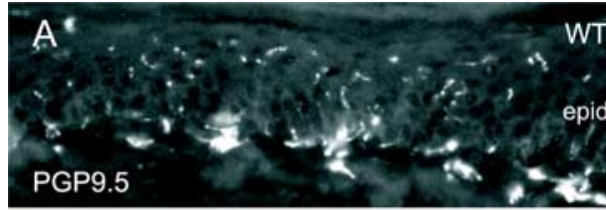

\section{C}
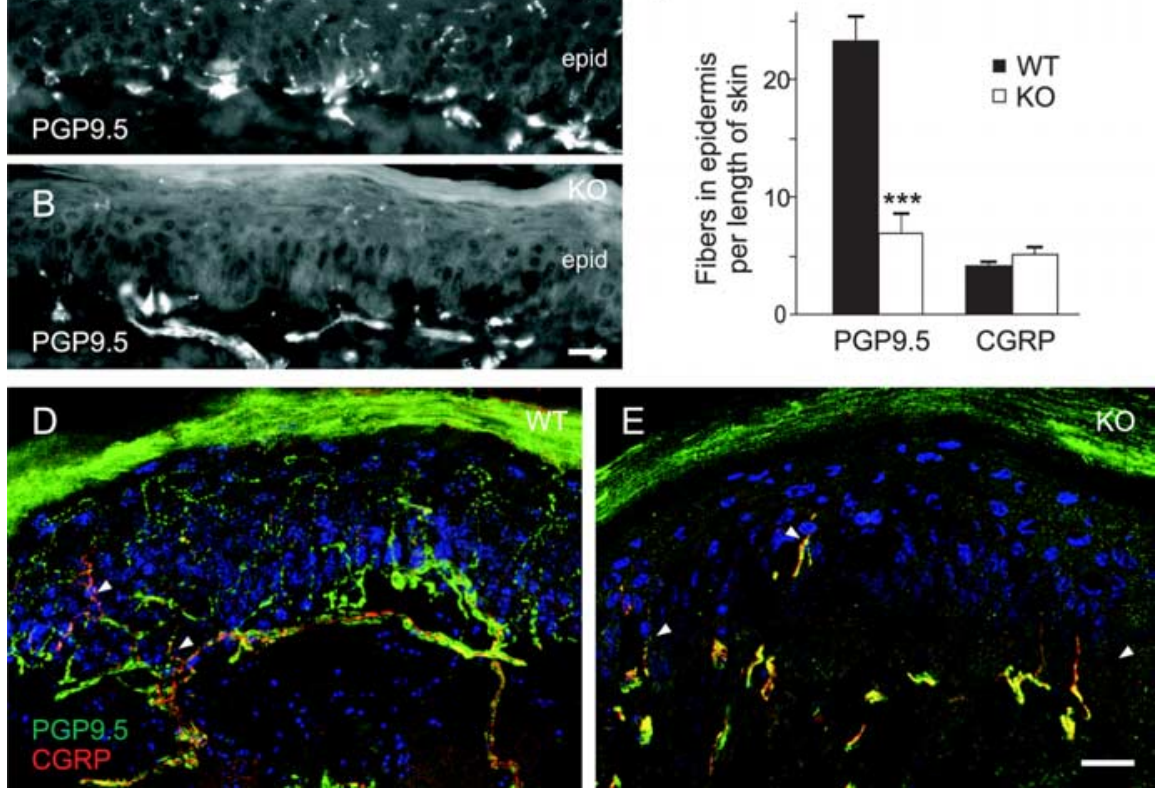

Figure 3. Loss of PGP9.5-positive but not CGRP-positive free nerve endings in the footpad epidermis in GFR $\alpha 2$-K0 mice. $\boldsymbol{A}, \boldsymbol{B}$, Conventional microscopic images of sections through the forepaw footpad skin from wild-type $(\boldsymbol{A})$ and GFR $\alpha 2$-KO (B) mice stained for pan-neuronal marker PGP9.5. C, Quantification of PGP9.5- and (GRP-positive nerve fibers per unit length of epidermis indicates profound loss of PGP9.5 fibers ( ${ }^{* * *} p<0.001 ; n=8$ mice in both genotypes), whereas the density of (GRP fibers is unchanged ( $n=4$ mice in both genotypes). Error bars represent SEM. $\boldsymbol{D}, \boldsymbol{E}$, Confocal microscopic images from sections through the footpad skin from wild-type (D) and GFR $\alpha 2$-KO (E) mice double stained for pan-neuronal marker PGP9.5 (green) and CGRP (red). Nuclei are counterstained with DAPI (blue). Arrowheads indicate PGP9.5 and (GRP double-positive fibers. Scale bars, $20 \mu \mathrm{m}$. tween the genotypes (supplemental material, available at www.jneurosci.org). This is consistent with the previous report using an in vitro skin-nerve preparation that neurons from GFR $\alpha 2-\mathrm{KO}$ mice show normal electrophysiological responses to mechanical stimulation (Stucky et al., 2002).

\section{Formalin-induced persistent pain is}

reduced in GFR $\alpha 2-K O$ mice

We measured nociceptive responses to chemogenic inflammatory pain using the formalin test (Murray et al., 1988) (Fig. $5 F$ ). Subcutaneous injection of formalin causes local tissue damage and acute activation of both myelinated and unmyelinated nociceptors (Puig and Sorkin, 1995). During the first acute phase, both wild-type and GFR $\alpha 2-\mathrm{KO}$ mice spent equally long licking and shaking the injected paw (WT, $72 \pm 11 \mathrm{~s} ; \mathrm{KO}, 56 \pm 9 \mathrm{~s}$; $p=0.3)$. However, in the second persistent phase, the formalin-induced pain behavior was significantly reduced in $\mathrm{KO}$ mice compared with their wild-type littermates (WT, $330 \pm 30 \mathrm{~s} ; \mathrm{KO}, 140 \pm 20 \mathrm{~s}$; $p=0.0001)$. Formalin-induced swelling of paws was similar between the genotypes (data not shown), indicating that the degree of inflammation was comparable.
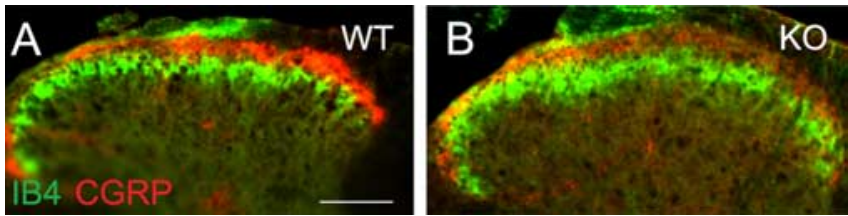

Figure 4. IB4 binding is unaltered in the GFR $\alpha 2-K 0$ spinal cord. Cryosections of wild-type $(\boldsymbol{A})$ and GFR $\alpha 2-K 0(B)$ mouse spinal cords were labeled with IB4 (green) and GRP (red). Scale bar, $100 \mu \mathrm{m}$.

withdrawal tests of noxious pain. In the hot plate test, no significant difference was present in the escape latency between GFR $\alpha 2-\mathrm{KO}$ and wild-type mice in a 129B6 hybrid background at plate temperatures of $52^{\circ} \mathrm{C}$ (Fig. $5 A$ ) or $49^{\circ} \mathrm{C}$ (data not shown). Similar results were obtained using mice in congenic B6 (Fig. 5A) and 129 (data not shown) backgrounds. In the tail immersion test, withdrawal latency at a water bath temperature of $52^{\circ} \mathrm{C}$ was similar between the genotypes (Fig. 5B). However, at a water temperature of $49^{\circ} \mathrm{C}$, the GFR $\alpha 2-\mathrm{KO}$ mice exhibited significantly shorter withdrawal latencies than the wild-type controls (Fig. $5 C)$. Moreover, the mutant mice exhibited much shorter latencies in the cold water $\left(4^{\circ} \mathrm{C}\right)$ tail withdrawal test (Fig. $\left.5 D\right)$. To assess sensitivity to innocuous warm temperatures, we used the two-temperature choice test. In accord with a previous report (Lee et al., 2005), wild-type mice did not distinguish between the temperatures of 34 and $36^{\circ} \mathrm{C}$, whereas they clearly preferred $35^{\circ} \mathrm{C}$ over room temperature (Fig. $5 E$ ). However, GFR $\alpha 2-\mathrm{KO}$ mice did not differ from their wild-type littermates in this test.

GFR $\alpha 2-K O$ mice show normal behavioral responses to tactile stimulation

We used calibrated von Frey filaments of increasing force to evoke paw withdrawal but did not observe any difference be-

\section{Discussion}

In this study, we show that nonpeptidergic C-fiber nociceptive neurons require GFR $\alpha 2$ for their size and cutaneous target innervation. We also demonstrate that GFR $\alpha 2$-deficiency in mice results in specific abnormalities in sensory tests.

We show that the average size of IB4-binding and $\mathrm{P}_{2} \mathrm{X}_{3}$ positive DRG neurons is reduced (by 30\%) in GFR $\alpha 2$-KO mice in vivo, consistent with the smaller caliber of unmyelinated axons in a cutaneous nerve in KO mice (Stucky et al., 2002). We assume that the shift in cell size distribution in the GFR $\alpha 2-\mathrm{KO}$ mice represents general atrophy of the nonpeptidergic DRG neurons that express GFR $\alpha 2$ in wild-type mice. However, it cannot be excluded that this shift is attributable to a more dramatic atrophy of only a subset of large nonpeptidergic neurons. The density of $\mathrm{P}_{2} \mathrm{X}_{3}$-positive neurons is not reduced in GFR $\alpha 2-\mathrm{KO}$ mice, consistent with our previous report of a normal number of IB4binding neurons and unmyelinated axons in the cutaneous nerve (Stucky et al., 2002). Thus, similar to many autonomic cholinergic neurons (Hiltunen and Airaksinen, 2004), GFR $\alpha 2$ signaling is required for cell size but not survival of a major subpopulation of cutaneous primary sensory neurons.

The most important result of this study is the profound $(>70 \%)$ reduction of nonpeptidergic epidermal nerve endings in adult GFR $\alpha 2-\mathrm{KO}$ mouse footpad. The epidermis receives robust innervation by small-caliber (mainly C- but also A $\delta$ ) fibers, the free nerve endings of which mediate thermal, mechanical, and pain sensation. Approximately half of the C-fiber nociceptors are CGRP positive, but only a subpopulation of them project to skin. Our estimate that $\sim 30 \%$ of all PGP9.5-positive nerve fibers in wild-type mouse foot pad epidermis are CGRP positive is comparable with another recent study (Zylka et al., 2005). The peptidergic class of cutaneous nociceptor expresses tyrosine receptor 
A

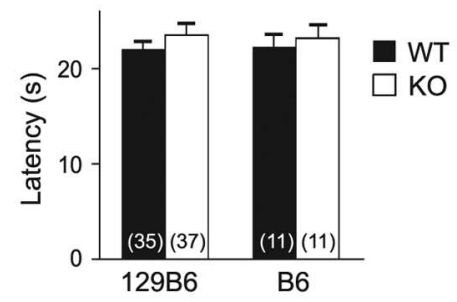

C
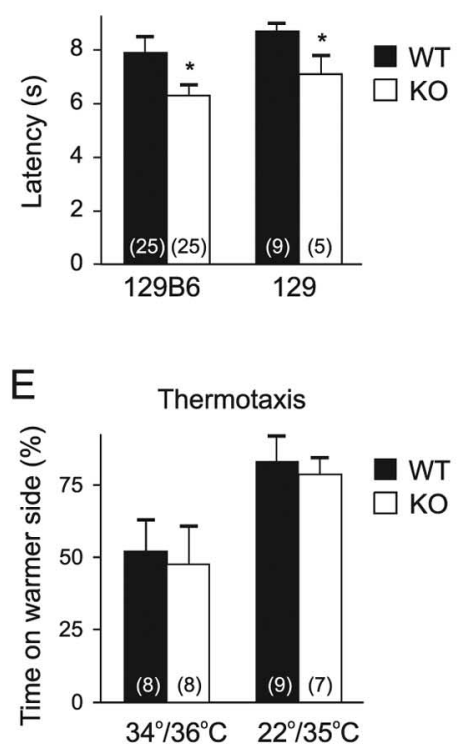

B

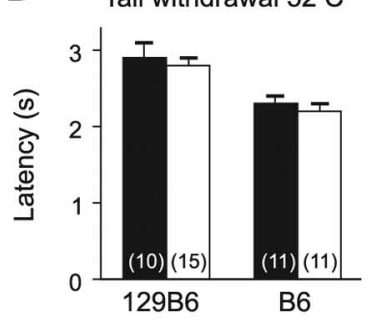

D Tail withdrawal $4^{\circ} \mathrm{C}$

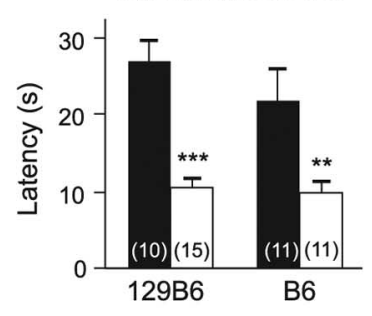

$\mathrm{F}$

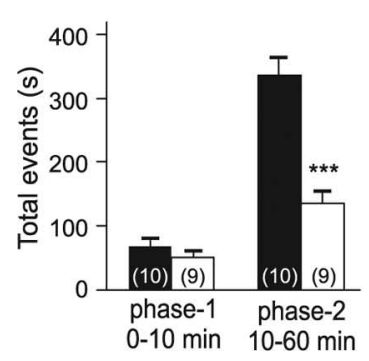

Figure 5. Behavioral analysis of cutaneous sensory responses in GFR $\alpha 2-K 0$ mice. Results using mice in $129 B 6$ hybrid and in congenic $B 6$ or 129 backgrounds are shown. The number of mice in each test is shown in parentheses. $A, B, G F R \alpha 2$-KO mice do not differ from their wildtype littermates in the $52^{\circ} \mathrm{C}$ hot plate $\left(\boldsymbol{A} ; 129 \mathrm{~B} 6, F_{(1,70)}=1.26, p=0.3 ; \mathrm{B} 6, F_{(1,20)}=0.21, p=\right.$ $0.7)$ or tail-withdrawal tests $\left(\boldsymbol{B} ; 129 \mathrm{~B} 6, F_{(1,23)}=0.17, p=0.7 ; \mathrm{B} 6, F_{(1,20)}=0.73, p=0.4\right)$. $\boldsymbol{C}$, $D$, Response latencies in GFR $\alpha 2$-K0 mice are shorter than in their wild-type littermates at $49^{\circ} \mathrm{C}$ $\left(\boldsymbol{C} ; 129 \mathrm{~B} 6, F_{(1,48)}=5.15,{ }^{*} p=0.03 ; 129, F_{(1,12)}=5.49,{ }^{*} p=0.04\right)$ and $4^{\circ} \mathrm{C}(\boldsymbol{D} ; 129 \mathrm{~B} 6$, $\left.F_{(1,23)}=42.58,{ }^{* * *} p<0.001 ; \mathrm{B} 6, F_{(1,20)}=7.95,{ }^{* *} p=0.01\right) . E$, GFR $\alpha 2$-KO mice do not differ from their wild-type littermates in responses to the warm two-temperature choice test (36 vs

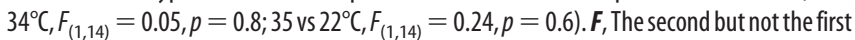
phase of formalin-induced pain behavior is impaired in GFR $\alpha 2$-KO mice. Hindpaw licking and shaking responses in wild-type $(n=10)$ and GFR $\alpha 2$-K0 mice $(n=9)$ in a B6 background after intraplantar injection of $5 \%$ formalin are shown. ${ }^{* *} p=0.0001$. Error bars represent SEM.

kinase A and requires its ligand nerve growth factor (NGF) postnatally from the skin for terminal arborization and sensitivity to thermal and chemical stimuli (Bennett et al., 1998a). As shown here, the peptidergic neurons do not express GFR $\alpha 2$ and remain unaffected in GFR $\alpha 2-\mathrm{KO}$ mice. Thus, our results indicate that most nonpeptidergic cutaneous sensory neurons require GFR $\alpha 2$ signaling for target innervation. The ability to genetically label this innervation (Zylka et al., 2005) should help to address whether GFR $\alpha 2$ signaling is required for the development or maintenance of epidermal nerve endings in the footpad, and whether epidermal innervation of other cutaneous areas have a similar requirement for GFR $\alpha 2$ signaling. A similar analysis of NRTN-KO mice could also be helpful.

Both GDNF and NRTN are expressed in developing mouse skin (Golden et al., 1999), and GFR $\alpha 1$ and GFR $\alpha 2$ are expressed in distinct but partly overlapping subpopulations of IB4-binding neurons (Bennett et al., 1998b), suggesting that the remaining

CGRP-negative nerve endings in GFR $\alpha 2$-KO mouse epidermis may be GDNF dependent. Interestingly, the morphological changes found in the cutaneous sensory neurons of GFR $\alpha 2-\mathrm{KO}$ mice, namely the reduced caliber of cutaneous axons (Stucky et al., 2002) and density of nonpeptidergic epidermal innervation (this study), are opposite to those found in mice overexpressing GDNF in skin keratinocytes (Zwick et al., 2002). Because in vivo signaling for GDNF and neurturin in sensory neurons is GFR $\alpha$ receptor-specific (Leitner et al., 1999), it is possible that the morphological changes in GDNF-overexpressing mice are restricted to the GFR $\alpha 1$-expressing subpopulation of cutaneous sensory neurons. It would be informative to compare sensory phenotype of these mice to mice overexpressing NRTN in skin.

We show here that behavioral responses to innocuous warm and noxious heat are not reduced in the GFR $\alpha 2-\mathrm{KO}$ mice in vivo, and thus the physiological relevance of the heat transduction deficit in vitro (Stucky et al., 2002) remains unclear. Transient receptor potential receptors are temperature-sensitive ion channels mainly expressed in different sensory neurons (Jordt et al., 2003; Patapoutian et al., 2003). We show that TRPV1 was not coexpressed with GFR $\alpha 2$ in wild-type mouse DRG, and the density of TRPV1-positive neurons was unchanged in GFR $\alpha 2-\mathrm{KO}$ mouse DRG (data not shown). Consistent with this, IB4-binding neurons do not express TRPV1 in mouse DRG (Zwick et al., 2002; Woodbury et al., 2004), suggesting that receptors other than TRPV1 transduce noxious heat in GFR $\alpha 2 /$ IB4-positive nociceptors. However, because neurotrophic factors (including GDNF) and peripheral inflammation increase TRPV1 expression and function in the IB4-positive sensory neurons (Amaya et al., 2004; Breese et al., 2005), a role for GFR $\alpha 2$ signaling in TRPV1mediated thermal hyperalgesia remains possible.

Recent studies of innocuous warm sensation suggest TRPV3 and TRPV4 receptors in skin keratinocytes as the sensors of warm stimulus, which transmit the signal to the epidermal sensory nerve endings (Lee et al., 2005; Moqrich et al., 2005). Our demonstration that mice lacking $50-70 \%$ of the epidermal nerve endings have no gross deficits in innocuous warm sensation may seem at odds with such a model. However, the remaining innervation may be sufficient for the KO mice to respond normally in the two-temperature choice test. The hypothesis that normal behavior can be exhibited despite dramatic anatomical changes is supported by a study in which NGF-deficient mice were rescued by transgenic expression of NGF in the skin. The response of these mice to noxious thermal stimuli was fully recovered, although the IB4-positive sensory neuron population was only modestly restored (Harrison et al., 2004).

NGF and the peptidergic nociceptors are important mediators of inflammatory pain (Snider and McMahon, 1998; Woolf and Costigan, 1999; Hunt and Mantyh, 2001), but recent studies suggest that the nonpeptidergic nociceptors are also involved (Breese et al., 2005). Consistent with this idea, we show that GFR $\alpha 2-\mathrm{KO}$ mice have reduced formalin-induced inflammatory pain response. The intact first-phase response in GFR $\alpha 2$-KO mice suggests that functional chemonociceptor terminals mediating the acute phase are present in $\mathrm{KO}$ mouse skin. Inflammationinduced hyperactivity of C-fibers generates and sustains an elevated discharge of dorsal horn neurons (Pitcher and Henry, 2002), which is thought to be critical for the second, persistent phase formalin response (Tjolsen et al., 1992; Puig and Sorkin, 1995; Taylor et al., 1995). Thus, a parsimonious explanation for the reduced second-phase response in GFR $\alpha 2$-KO mice would be weaker activation of the nonpeptidergic DRG neurons. However, the behavioral pain response involves a network of neurons and 
other cells and is modulated at several levels. Whether the reduced formalin-induced inflammatory pain response in GFR $\alpha 2-\mathrm{KO}$ mice involves peripheral and/or central component mechanisms and whether pain responses in the $\mathrm{KO}$ mice are altered in other models of inflammatory pain remain to be studied.

Interestingly, formalin-induced inflammatory pain is inhibited by specific $\mathrm{P}_{2} \mathrm{X}_{3}$ blockers (Tsuda et al., 1999; McGaraughty et al., 2003) and in mice lacking $\mathrm{P}_{2} \mathrm{X}_{3}$ (Cockayne et al., 2000; Souslova et al., 2000). The $\mathrm{P}_{2} \mathrm{X}_{3}$-deficient mice also have a remarkably similar temperature sensation phenotype to the GFR $\alpha 2-\mathrm{KO}$ mice, including shorter withdrawal latencies at temperatures above and below thermoneutrality in the tail flick test (Shimizu et al., 2005). The extensive colocalization between GFR $\alpha 2$ and $\mathrm{P} 2 \mathrm{X}_{3}$ in DRG neurons suggests that the loss of nonpeptidergic nerve fibers in the GFR $\alpha 2-\mathrm{KO}$ mouse epidermis represents predominantly $\mathrm{P} 2 \mathrm{X}_{3}$-positive nerve endings. Thus, an intriguing possibility is that attenuated inflammatory pain response (and enhanced thermal avoidance) in GFR $\alpha 2-\mathrm{KO}$ mice is a result of reduced activation of $\mathrm{P}_{2} \mathrm{X}_{3}$. Another candidate mediator for the reduced inflammatory pain is bradykinin $\mathrm{B} 1$ receptor, the expression of which in nociceptive neurons can be upregulated by neurturin (Vellani et al., 2004). A number of other molecules contribute to inflammatory pain, including immune and glial cell factors involved in the inflammatory response (Marchand et al., 2005).

In conclusion, we have shown that the majority of nonpeptidergic cutaneous free nerve endings in the mouse footpad require GFR $\alpha 2$ signaling. In addition, this signal is required to maintain the size of the corresponding unmyelinated nociceptive sensory neurons. We propose that NRTN, the cognate GFR $\alpha 2$ ligand expressed in the epidermis (Golden et al., 1999), may act as a short-range factor that helps the C-fiber terminals to branch, grow, and remain in the relatively repulsive environment of the epidermis (Cahoon and Scott, 1999). In addition to being distinct in terms of trophic requirements, molecular markers, and spinal projections (Snider and McMahon, 1998; Hunt and Mantyh, 2001), recent studies suggest that the peptidergic and nonpeptidergic subsets of polymodal nociceptors differ in their intracellular mechanisms of sensitization (Hucho et al., 2005), skin innervation patterns (Zylka et al., 2005), and ascending pathways to the brain (Braz et al., 2005). GFR $\alpha 2-\mathrm{KO}$ mice provide a unique model to test the role of nonpeptidergic cutaneous innervation in pain and other sensory functions.

Reduced density of epidermal nerve endings is a general finding in human neuropathic syndromes (Chien et al., 2001), including diabetic and idiopathic small fiber neuropathy (Holland et al., 1997) and postherpetic neuralgia (Fields et al., 1998; Oaklander, 2001), and is correlated with clinical severity. Remarkably, loss of epidermal innervation is often found without obvious defect in the peripheral nerve (Periquet et al., 1999; Herrmann et al., 1999), raising the possibility of altered NRTN/ GFR $\alpha 2$ signaling in these conditions. Because NRTN treatment has been shown to stimulate growth and branching of cutaneous axons in diabetic mice (Christianson et al., 2003), the GFR $\alpha 2$ signaling pathway appears to be a potential target of therapy for sensory regeneration and persistent pain.

\section{References}

Airaksinen MS, Saarma M (2002) The GDNF family: signalling, biological functions and therapeutic value. Nat Rev Neurosci 3:383-394.

Amaya F, Shimosato G, Nagano M, Ueda M, Hashimoto S, Tanaka Y, Suzuki H, Tanaka M (2004) NGF and GDNF differentially regulate TRPV1 expression that contributes to development of inflammatory thermal hyperalgesia. Eur J Neurosci 20:2303-2310.
Baloh RH, Enomoto H, Johnson EMJ, Milbrandt J (2000) The GDNF family ligands and receptors-implications for neural development. Curr Opin Neurobiol 10:103-110.

Banbury Conference on Genetic Background in Mice (1997) Mutant mice and neuroscience: recommendations concerning genetic background. Neuron 19:755-759.

Baudet C, Mikaels A, Westphal H, Johansen J, Johansen TE, Ernfors P (2000) Positive and negative interactions of GDNF, NTN and ART in developing sensory neuron subpopulations, and their collaboration with neurotrophins. Development 127:4335-4344.

Bennett DL, Koltzenburg M, Priestley JV, Shelton DL, McMahon SB (1998a) Endogenous nerve growth factor regulates the sensitivity of nociceptors in the adult rat. Eur J Neurosci 10:1282-1291.

Bennett DL, Michael GJ, Ramachandran N, Munson JB, Averill S, Yan Q, McMahon SB, Priestley JV (1998b) A distinct subgroup of small DRG cells express GDNF receptor components and GDNF is protective for these neurons after nerve injury. J Neurosci 18:3059-3072.

Braz JM, Nassar MA, Wood JN, Basbaum AI (2005) Parallel "pain” pathways arise from subpopulations of primary afferent nociceptor. Neuron 47:787-793.

Breese NM, George AC, Pauers LE, Stucky CL (2005) Peripheral inflammation selectively increases TRPV1 function in IB4-positive sensory neurons from adult mouse. Pain 115:37-49.

Cahoon SM, Scott SA (1999) Multiple mechanisms contribute to the avoidance of avian epidermis by sensory axons. Dev Biol 208:502-512.

Chien HF, Tseng TJ, Lin WM, Yang CC, Chang YC, Chen RC, Hsieh ST (2001) Quantitative pathology of cutaneous nerve terminal degeneration in the human skin. Acta Neuropathol (Berl) 102:455-461.

Christianson JA, Riekhof JT, Wright DE (2003) Restorative effects of neurotrophin treatment on diabetes-induced cutaneous axon loss in mice. Exp Neurol 179:188-199.

Cockayne DA, Hamilton SG, Zhu QM, Dunn PM, Zhong Y, Novakovic S, Malmberg AB, Cain G, Berson A, Kassotakis L, Hedley L, Lachnit WG, Burnstock G, McMahon SB, Ford AP (2000) Urinary bladder hyporeflexia and reduced pain-related behaviour in P2X3-deficient mice. Nature 407:1011-1015.

Fields HL, Rowbotham M, Baron R (1998) Postherpetic neuralgia: irritable nociceptors and deafferentation. Neurobiol Dis 5:209-227.

Golden JP, DeMaro JA, Osborne PA, Milbrandt J, Johnson Jr EM (1999) Expression of neurturin, GDNF, and GDNF family-receptor mRNA in the developing and mature mouse. Exp Neurol 158:504-528.

Harrison SMW, Davis BM, Nishimura M, Albers KM, Jones ME, Phillips HS (2004) Rescue of NGF-deficient mice I: transgenic expression of NGF in skin rescues mice lacking endogenous NGF. Mol Brain Res 122:116-125.

Herrmann DN, Griffin JW, Hauer P, Cornblath DR, McArthur JC (1999) Epidermal nerve fiber density and sural nerve morphometry in peripheral neuropathies. Neurology 53:1634-1640.

Heuckeroth RO, Enomoto H, Grider JR, Golden JP, Hanke JA, Jackman A, Molliver DC, Bardgett ME, Snider WD, Johnson EMJ, Milbrandt J (1999) Gene targeting reveals a critical role for neurturin in the development and maintenance of enteric, sensory, and parasympathetic neurons. Neuron 22:253-263.

Hiltunen PH, Airaksinen MS (2004) Sympathetic cholinergic target innervation requires GDNF family receptor GFR $\alpha 2$. Mol Cell Neurosci 26:450-457.

Hiltunen PH, Voikar V, Rossi J, Airaksinen MS (2003) Lack of fine nerve endings in epidermis and reduced sensitivity to noxious heat in GFR $\alpha 2$ knockout mice. Soc Neurosci Abstr 29:886.3.

Holland NR, Stocks A, Hauer P, Cornblath DR, Griffin JW, McArthur JC (1997) Intraepidermal nerve fiber density in patients with painful sensory neuropathy. Neurology 48:708-711.

Hucho TB, Dina OA, Levine JD (2005) Epac mediates a cAMP-to-PKC signaling in inflammatory pain: an isolectin $\mathrm{B} 4(+)$ neuron-specific mechanism. J Neurosci 25:6119-6126.

Hunt SP, Mantyh PW (2001) The molecular dynamics of pain control. Nat Rev Neurosci 2:83-91.

Jordt SE, McKemy DD, Julius D (2003) Lessons from peppers and peppermint: the molecular logic of thermosensation. Curr Opin Neurobiol 13:487-492.

Josephson A, Widenfalk J, Trifunovski A, Widmer HR, Olson L, Spenger C (2001) GDNF and NGF family members and receptors in human fetal 
and adult spinal cord and dorsal root ganglia. J Comp Neurol 440:204-217.

Kotzbauer PT, Lampe PA, Heuckeroth RO, Golden JP, Creedon DJ, Johnson Jr EM, Milbrandt J (1996) Neurturin, a relative of glial-cell-line-derived neurotrophic factor. Nature 384:467-470.

Lee H, Iida T, Mizuno A, Suzuki M, Caterina MJ (2005) Altered thermal selection behavior in mice lacking transient receptor potential vanilloid 4 . J Neurosci 25:1304-1310.

Leitner ML, Molliver DC, Osborne PA, Vejsada R, Golden JP, Lampe PA, Kato AC, Milbrandt J, Johnson EMJ (1999) Analysis of the retrograde transport of glial cell line-derived neurotrophic factor (GDNF), neurturin, and persephin suggests that in vivo signaling for the GDNF family is GFR $\alpha$ coreceptor-specific. J Neurosci 19:9322-9331.

Luukko K, Saarma M, Thesleff I (1998) Neurturin mRNA expression suggests roles in trigeminal innervation of the first branchial arch and in tooth formation. Dev Dyn 213:207-219.

Marchand F, Perretti M, McMahon SB (2005) Role of the immune system in chronic pain. Nat Rev Neurosci 6:521-532.

McGaraughty S, Wismer CT, Zhu CZ, Mikusa J, Honore P, Chu KL, Lee CH, Faltynek CR, Jarvis MF (2003) Effects of A-317491, a novel and selective $\mathrm{P} 2 \mathrm{X}_{3} / \mathrm{P} 2 \mathrm{X}_{2 / 3}$ receptor antagonist, on neuropathic, inflammatory and chemogenic nociception following intrathecal and intraplantar administration. Br J Pharmacol 140:1381-1388.

Mogil JS, Lichtensteiger CA, Wilson SG (1998) The effect of genotype on sensitivity to inflammatory nociception: characterization of resistant $(\mathrm{A} / \mathrm{J})$ and sensitive (C57BL/6J) inbred mouse strains. Pain 76:115-125.

Molliver DC, Wright DE, Leitner ML, Parsadanian AS, Doster K, Wen D, Yan Q, Snider WD (1997) IB4-binding DRG neurons switch from NGF to GDNF dependence in early postnatal life. Neuron 19:849-861.

Moqrich A, Hwang SW, Earley TJ, Petrus MJ, Murray AN, Spencer KS, Andahazy M, Story GM, Patapoutian A (2005) Impaired thermosensation in mice lacking TRPV3, a heat and camphor sensor in the skin. Science 307:1468-1472.

Murray CW, Porreca F, Cowan A (1988) Methodological refinements to the mouse paw formalin test. An animal model of tonic pain. J Pharmacol Methods 20:175-186.

Oaklander AL (2001) The density of remaining nerve endings in human skin with and without postherpetic neuralgia after shingles. Pain 92:139-145.

Patapoutian A, Peier AM, Story GM, Viswanath V (2003) ThermoTRP channels and beyond: mechanisms of temperature sensation. Nat Rev Neurosci 4:529-539.

Paveliev M, Airaksinen MS, Saarma M (2004) GDNF family ligands activate multiple events during axonal growth in mature sensory neurons. Mol Cell Neurosci 25:453-459.

Periquet MI, Novak V, Collins MP, Nagaraja HN, Erdem S, Nash SM, Freimer ML, Sahenk Z, Kissel JT, Mendell JR (1999) Painful sensory neuropathy: prospective evaluation using skin biopsy. Neurology 53:1641-1647.

Pitcher GM, Henry JL (2002) Second phase of formalin-induced excitation of spinal dorsal horn neurons in spinalized rats is reversed by sciatic nerve block. Eur J Neurosci 15:1509-1515.

Plenderleith MB, Snow PJ (1993) The plant lectin Bandeiraea simplicifolia I-B4 identifies a subpopulation of small diameter primary sensory neurons which innervate the skin in the rat. Neurosci Lett 159:17-20.

Puig S, Sorkin LS (1995) Formalin-evoked activity in identified primary afferent fibers: systemic lidocaine suppresses phase-2 activity. Pain 64:345-355.

Rossi J, Luukko K, Poteryaev D, Laurikainen A, Sun Y-F, Laakso T, Eerikäinen S, Tuominen R, Lakso M, Rauvala H, Arumäe U, Saarma M, Airaksinen MS (1999) Retarded growth and deficits in the enteric and parasympathetic nervous system in mice lacking GFR $\alpha 2$, a functional neurturin receptor. Neuron 22:243-252.

Shimizu I, Iida T, Guan Y, Zhao C, Raja SN, Jarvis MF, Cockayne DA, Caterina MJ (2005) Enhanced thermal avoidance in mice lacking the ATP receptor P2X(3). Pain 116:96-108.

Snider WD, McMahon SB (1998) Tackling pain at the source: new ideas about nociceptors. Neuron 20:629-632.

Souslova V, Cesare P, Ding Y, Akopian AN, Stanfa L, Suzuki R, Carpenter K, Dickenson A, Boyce S, Hill R, Nebenuis-Oosthuizen D, Smith AJ, Kidd EJ, Wood JN (2000) Warm-coding deficits and aberrant inflammatory pain in mice lacking P2X3 receptors. Nature 407:1015-1017.

Stucky CL, Rossi J, Airaksinen MS, Lewin GR (2002) GFR alpha2/neurturin signalling regulates noxious heat transduction in isolectin B4-binding mouse sensory neurons. J Physiol (Lond) 545:43-50.

Taylor BK, Peterson MA, Basbaum AI (1995) Persistent cardiovascular and behavioral nociceptive responses to subcutaneous formalin require peripheral nerve input. J Neurosci 15:7575-7584.

Tjolsen A, Berge OG, Hunskaar S, Rosland JH, Hole K (1992) The formalin test: an evaluation of the method. Pain 51:5-17.

Tsuda M, Ueno S, Inoue K (1999) Evidence for the involvement of spinal endogenous ATP and P2X receptors in nociceptive responses caused by formalin and capsaicin in mice. Br J Pharmacol 128:1497-1504.

Vellani V, Zachrisson O, McNaughton PA (2004) Functional bradykinin B1 receptors are expressed in nociceptive neurones and are upregulated by the neurotrophin GDNF. J Physiol (Lond) 560:391-401.

Woodbury CJ, Zwick M, Wang S, Lawson JJ, Caterina MJ, Koltzenburg M, Albers KM, Koerber HR, Davis BM (2004) Nociceptors lacking TRPV1 and TRPV2 have normal heat responses. J Neurosci 24:6410-6415.

Woolf CJ, Costigan M (1999) Transcriptional and posttranslational plasticity and the generation of inflammatory pain. Proc Natl Acad Sci USA 96:7723-7730.

Zwick M, Davis BM, Woodbury CJ, Burkett JN, Koerber HR, Simpson JF, Albers KM (2002) Glial cell line-derived neurotrophic factor is a survival factor for isolectin B4-positive, but not vanilloid receptor 1-positive, neurons in the mouse. J Neurosci 22:4057-4065.

Zylka MJ, Rice FL, Anderson DJ (2005) Topographically distinct epidermal nociceptive circuits revealed by axonal tracers targeted to Mrgprd. Neuron 45:17-25. 